\author{
MICHAE JASIŃSKI \\ Szkoła Główna Handlowa w Warszawie, Polska \\ Warsaw School of Economics, Poland
}

\title{
Nasycenie gospodarki turystyka a poziom rozwoju społeczno-ekonomicznego w małych rozwijających się państwach wyspiarskich
}

\section{Tourism Penetration and the Socio-Economic Development Level of Small Island Developing States}

\begin{abstract}
Streszczenie: Przedmiotem artykułu jest zbadanie stopnia nasycenia gospodarki turystyką i poziomu rozwoju społeczno-ekonomicznego w 29 małych rozwijających się państwach wyspiarskich. Stopień nasycenia gospodarki turystyką wyznaczono przy zastosowaniu wskaźnika Tourism Penetration Index (TPI) - indeksu, którego konstrukcja opiera się na trzech płaszczyznach: ekonomicznej, społeczno-kulturowej i przestrzennej. Poziom rozwoju społeczno-ekonomicznego wyznaczono w oparciu o wskaźnik rozwoju społecznego (Human Development Index, HDI) i zamożności (dochód narodowy na osobę). Przeprowadzone analizy wykazały, że gospodarki o wysokim i średnim stopniu nasycenia gospodarki turystyką charakteryzowały się wyższym poziomem rozwoju społeczno-ekonomicznego. Wyniki badania stanowią element przemawiający na korzyść (z perspektywy ekonomicznej) w dyskusji nad oceną monokultury turystycznej. Zjawiska, które zarówno w literaturze z zakresu geografii turystyki, jak i ekonomiki turystyki postrzegane jest na ogół jednostronnie negatywnie.
\end{abstract}

\begin{abstract}
The aim of article is an analysis of tourism penetration and the socio-economic development level of 29 small island developing states (SIDS). The tourism penetration was measured by Tourism Penetration Index (TPI) which is divided into three aspects of tourism impacts: economic, social, and special. The level of socio-economic development was assessed with the use of Human Development Index (HDI) and Gross national income (GNI) per capita. The analysis shows that economies with high and medium tourism penetration were on the highest economic development level. The research results shows that "tourism monoculture" from the economic point of view can have positive aspects.
\end{abstract}

Słowa kluczowe: małe państwa wyspiarskie; monokultura turystyczna; rozwój społeczno-ekonomiczny Keywords: small island countries; socio-economic development; tourism monoculture

Otrzymano: 6 stycznia 2018

Received: 6 January 2018

Zaakceptowano: 15 maja 2018

Accepted: 15 May 2018 


\section{Sugerowana cytacja / Suggested citation:}

Jasiński, M. (2018). Nasycenie gospodarki turystyką a poziom rozwoju społeczno-ekonomicznego w małych rozwijających się państwach wyspiarskich. Prace Komisji Geografii Przemysłu Polskiego Towarzystwa Geograficznego, 32(2), 311-324. https://doi.org/10.24917/20801653.322.22

\section{WSTĘP}

Małe państwa (terytoria) wyspiarskie (Small Island Developing States, SIDS) stanowią specyficzną grupę, której gospodarki charakteryzują się kruchością (vulnerability), wynikającą z cech geograficznych (małe rozmiary, ograniczone zasoby naturalne, izolacja, klęski żywiołowe). Determinują one wąską specjalizację gospodarczą i marginalne znaczenie w handlu międzynarodowym. Gospodarki te m.in. nie są w stanie wykorzystać efektu skali, uzależnione są od importu, charakteryzują się niskim stopniem wykorzystania zasobów pracy, kulturową dominacją Północy, wysokimi kosztami transportu, infrastruktury i administracji oraz podatnością na działalność przestępczą (pranie brudnych pieniędzy, narkotyki, korupcja) (Jasiński, 2017b).

Ograniczone możliwości specjalizacji gospodarczej SIDS powodują, że w dominujących przypadkach rozwój turystyki międzynarodowej wydaje się jedyną możliwością przełamania stagnacji społeczno-gospodarczej w tej grupie państw. Jej rozwój (w specyficznych wyspiarskich warunkach) wywołuje na ogół zjawisko określone w polskiej literaturze z zakresu ekonomiki turystyki jako „monokultura turystyczna” (Giezgała, 1969; 1977; Wodejko, 1998; Jasiński, 2006; 2008a; 2008b; 2013; 2017b; Kachniewska, Niezgoda, Pawlicz, 2012; Kowalczyk-Anioł, 2017). Zjawisko to z reguły postrzegane jest negatywnie. Wynika to nie tylko z akcentowania występujących licznych dysfunkcji stricte ekonomicznych (m.in. presja inflacyjna, „wycieki”, bariera siły roboczej, konieczność ponoszenia kosztów infrastruktury turystycznej i jej obsługi, zależność ekonomiczna), ale również wykształcenia się (przez intensywny rozwój turystyki) agresywnych form przestrzeni turystycznej (przestrzeń kolonizacji turystycznej), jak i licznych dysfunkcji społecznych (Jędrusik, 2003; Meyer, 2008; Włodarczyk, 2009). Spojrzenie to nie do końca jest zasadne z ekonomicznego punktu widzenia, ponieważ osadzone jest w postrzeganiu SIDS przez pryzmat gospodarek państw wysoko rozwiniętych - nieuwzględniający specyfiki małych rozwijających się państw wyspiarskich (Jasiński, 2008b).

Wystąpienie monokultury turystycznej w części SIDS, wiążące się z wysokim stopniem nasycenia gospodarki turystyką (dojrzałą fazą rozwoju gospodarki turystycznej), przyczynia się również do przyspieszenia procesu rozwoju społeczno-gospodarczego w tych państwach, co jest istotnym argumentem przemawiającym na korzyść w dyskusji nad oceną tego zjawiska. Zaistnienie tej zależności stanowi pretekst do próby odpowiedzi na pytanie, czy stopień nasycenia gospodarki turystyką determinuje poziom rozwoju małych rozwijających się państw wyspiarskich.

W wyniku braku powszechnie akceptowanych kryteriów klasyfikacji SIDS, na potrzeby artykułu autor odwołał się do „nieoficjalnej (roboczej) listy” Konferencji Narodów Zjednoczonych ds. Handlu i Rozwoju (UNCTAD, 2010), która za małe rozwijające się gospodarki wyspiarskie przyjmuje 29 niepodległych państw: 13 położonych na Oceanii (Federacyjne Stany Mikronezji, Fidżi, Kiribati, Nauru, Palau, Papua Nowa Gwinea, Samoa, Timor Wschodni, Tuvalu, Vanuatu, Wyspy Marshalla, Wyspy Salomona oraz Wyspy Tonga); 10 karaibskich (Antigua i Barbuda, Bahamy, Barbados, Dominika, 
Grenada, Jamajka, Saint Kitts i Nevis, Saint Lucia, Saint Vincent i Grenadyny oraz Trynidad i Tobago); dwa położone na Atlantyku Wschodnim (Republika Zielonego Przylądka oraz Wyspy Świętego Tomasza i Książęca) oraz cztery na Oceanie Indyjskim (Malediwy, Mauritius, Seszele oraz Związek Komorów) ${ }^{1}$.

\section{TPI JAKO NARZĘDZIE POMIARU STOPNIA NASYCENIA GOSPODAREK WYSPIARSKICH TURYSTYKĄ}

Punktem wyjścia do pomiaru stopnia nasycenia gospodarki turystyką w małych państwach wyspiarskich jest odwołanie się do wskaźnika TPI (McElroy, de Albuquerque, 1998; McElroy, 2003; 2004; Padilla, McElroy, 2005; McElroy, 2006) - indeksu, który oprócz ekonomicznych skutków turystyki normuje czynnik wpływu postępującej degradacji walorów turystycznych i przeciążenia infrastruktury w wyniku turystyki przyjazdowej. Jego konstrukcja opiera się na trzech płaszczyznach, na które oddziałuje turystyka recepcyjna: ekonomicznej, społeczno-kulturowej i przestrzennej (ekologicznej) (Jasiński, 2006; 2008a; 2013).

Efekt ekonomiczny oblicza się, przeliczając (łączne) wpływy z tytułu (zagranicznego) przyjazdowego ruchu turystycznego (tourism receipts), czy też - używając innego sformułowania - wpływy z eksportu produktu turystycznego (por. Wodejko, 1998), uzyskane w okresie jednego roku na jednego (stałego) mieszkańca. Na potrzeby dalszych rozważań można zapisać to symbolicznie jako EPT/per capita.

Efekty społeczno-kulturowe, określone dosłownie gęstością (density) zaludnienia, stanowią wyliczenie tzw. siły używania przestrzeni (wyspy) przez odwiedzających międzynarodowych turystów w stosunku do ludności miejscowej z uwzględnieniem określonego czynnika czasu (jednego roku). Siłę używania wyspy wylicza się według formuły:

$$
\text { SU }=[(\text { LT } x \text { ŚPT })+\text { LO }]:[L S M \times 365) \times 0,001]
$$

gdzie:

SU - to siła używania,

LT - to liczba turystów,

ŚPT - to średni pobyt turystów (dni),

LO - to liczba odwiedzających jednodniowych,

LSM - to liczba stałych mieszkańców.

Efekty ekologiczne (czy też stopień rozwoju przestrzeni turystycznej) oblicza się, przeliczając (łączną) liczbę pokoi hotelowych na $1 \mathrm{~km}^{2}$, co można symbolicznie zapisać jako $\mathrm{LPH} / \mathrm{km}^{2}$.

Uzyskane trzy wartości zestawia się przy zastosowaniu wzoru:

$$
\left(\mathrm{X}-\mathrm{X}_{\min }\right):\left(\mathrm{X}_{\max }-\mathrm{X}_{\min }\right)
$$

1 Klasyfikacja ta budzi wiele kontrowersji i zastrzeżeń (por. Encontre, 2004; Hein, 2004). Rozpatrując ją z perspektywy geograficznej, wątpliwości budzi m.in. zaklasyfikowanie wysp średnich (Trynidad i Tobago, Mauritius, Republika Zielonego Przylądka, Samoa oraz Związek Komorów), dużych (Bahamy, Fidżi, Jamajka, Timor Wschodni, Vanuatu oraz Wyspy Salomona) oraz bardzo dużych (Papua Nowa Gwinea) - por. tab. 1, kolumny: D i E. 
Otrzymuje się wartości EPT/per capita, SU i LPH/ $\mathrm{km}^{2}$ dla poszczególnych (X) badanych obszarów wyspiarskich. Następnie z uzyskanych wartości wyciąga się średnią (arytmetyczną), co można zapisać w postaci:

$$
\mathrm{TPI}_{\mathrm{x}}=\left(\mathrm{EPT} / \text { per } \text { capita }_{\mathrm{x}}+\mathrm{SU}_{\mathrm{x}}+\mathrm{LP} / \mathrm{km}_{\mathrm{x}}{ }_{\mathrm{x}}\right): 3
$$

uzyskując wysokość wskaźnika TPI dla poszczególnego (X) państwa².

\section{STOPIEŃ NASYCENIA MAEYCH ROZWIJAJĄCYCH SIĘ GOSPODAREK WYSPIARSKICH TURYSTYKĄ}

Na podstawie uzyskanych wskaźników (tab. 2), w wyniku aplikacji danych (tab. 1) z 2015 roku (bądź zbliżonych), stwierdzić można, że wysoki stopień intensyfikacji ruchu turystycznego oraz „zaboru przestrzeni” pod infrastrukturę turystyczną przekłada się na wysokie wpływy z eksportu produktu turystycznego. Przyjąć można, że Malediwy, Palau, Bahamy, Seszele, Antigua i Barbuda, Barbados, St. Kitts i Nevis oraz St. Lucia (wskaźnik TPI w przedziale od 0,800 do 0,200) znajdują się w dojrzałej fazie kolonizacji turystycznej, czy - ujmując to z innej perspektywy - są w dojrzałej fazie rozwoju gospodarki turystycznej, bądź też jeszcze inaczej - ich gospodarki są w wysokim stopniu nasycone przez sektor turystyczny. Rozumując w ten sposób, pozostałe SIDS o średnim wskaźniku (od 0,199 do 0,050) uznać należy za średnio nasycone turystyką. Wyspy o niskim TPI (poniżej 0,049) znajdują się zaś w inicjalnej fazie rozwoju gospodarki turystycznej (gospodarka w niewielkim stopniu jest nasycona turystyką) (tab. 2).

Akceptując ten punkt widzenia, trzeba stwierdzić, że za daleko posunięte jest uogólnienie, zakładające, że tam, gdzie przestrzeń kolonizacji turystycznej powstała wcześniej, stopień „skolonizowania turystycznego” jest największy. Nie należy również zakładać, że gospodarcze znaczenie turystyki jest większe. Przedstawione wyniki badania nie potwierdzają też ogólnie przyjętego schematu - faza inicjalna rozwoju turystyki: Melanezja; faza inicjalno-przejściowa: Polinezja, Atlantyk Wschodni; faza przejściowa: Mikronezja, Ocean Indyjski; faza przejściowo-dojrzała: Malaje; faza dojrzała: Karaiby (Jędrusik, 2005; Jasiński, 2008a), który zakłada, że stopień rozwoju przestrzeni (kolonizacji) turystycznej jest względnie jednolity (w poszczególnych wyspach tropikalnych) na oceanach. Utożsamienie wysokich wpływów z eksportu produktu turystycznego z dojrzałą fazą rozwoju gospodarki turystycznej w SIDS wydawać się może zbyt dużym uproszczeniem. Są one nadal często mylnie utożsamiane z liczbą odwiedzających i tempem wzrostu (por. Bahamy, Fidżi, Jamajka, Malediwy, Mauritius - tab. 1, kolumny A, C i G, tab. 2, kolumny EPT per capita, SU).

Opierając się na uzyskanych wartościach TPI dla badanych SIDS, stwierdzić można, że wysoki wskaźnik sygnalizuje granicę specjalizacji turystycznej. Jest ona w przypadku małych państw wyspiarskich wyznaczana przez ograniczoną przestrzeń geograficzną (por. tab. 1, kolumna E). Wysokie wskaźniki cząstkowe TPI (tab. 2), np. SU (Antigua i Barbuda, Bahamy, Palau, St. Kitts i Nevis) czy LPH/ $\mathrm{km}^{2}$ (Malediwy), są sygnałem ostrzegawczym dla postępującej degradacji walorów turystycznych oraz przeciążenia infrastruktury wynikłego z zagranicznej turystyki przyjazdowej. Pozostałe

2 Na temat metodologii wskaźnika TPI i jego wariantów szerzej patrz: McElroy, de Albuquerque (1998), McElroy (2003; 2004; 2006), Padilla, McElroy (2005). 
terytoria o niższych wartościach wskaźników mają zatem (teoretyczną) możliwość dalszego rozwoju przestrzeni turystycznej (gospodarki turystycznej) - podążania turystyczną ścieżką rozwojową, gdyż nasycenie turystyczne nie zostało jeszcze przez nie osiągnięte.

Stosując w analizie małych państw wyspiarskich wskaźnik TPI, trzeba jednak mieć świadomość, że uzyskane wartości mają charakter względny. Przy jego zastosowaniu trudno jest (precyzyjnie) wyznaczyć granicę specjalizacji turystycznej. Na podstawie wieloletnich badań (por. McElroy, de Albuquerque, 1998; McElroy 2003; 2004; Padilla, McElroy, 2005; McElroy, 2006; Jasiński, 2013) należy stwierdzić, że granica ta w SIDS stale się przesuwa. Przedstawione rozważania pozwalają sformułować wniosek, że małe państwa wyspiarskie charakteryzują się bardzo niskim progiem nasycenia gospodarki turystyką (w porównaniu z większymi ${ }^{3}$ państwami kontynentalnymi). W oparciu o wyniki wskaźnika TPI (2015) stwierdzić należy, że w przypadku: Malediwów, Palau, Bahamów, Seszeli, Antigui i Barbudy, Barbadosu, St. Kitts i Nevis oraz St. Lucii przestrzeń kolonizacji turystycznej jest dojrzała oraz gospodarki tych państw bliskie są osiągnięcia granicy jej nasycenia przez turystykę.

\section{POZIOM ROZWOJU SPOŁECZNO-EKONOMICZNEGO W MAŁYCH ROZWIJAJĄCYCH SIĘ PAŃSTWACH WYSPIARSKICH}

Specyfika małych państw wyspiarskich (podobnie jak pozostałych państw rozwijających się) skłania do alternatywnego podejścia do analizy działalności gospodarczej. Jest nim szeroko rozumiany rozwój społeczny - mieszczący w sobie pojęcia wzrostu i rozwoju gospodarczego (Bartkowiak, 2013; Mirkowska-Ostatek, 2013). Perspektywa ta, wywodząca się z koncepcji A. Sena (2002), znalazła uznanie i jest powszechnie akceptowana w literaturze przedmiotu. Metodą oceny efektywności tak pojmowanego gospodarowania jest wskaźnik rozwoju społecznego (HDI).

Na podstawie analizy wskaźnika HDI dla 26 SIDS (na podstawie: Human Development Report, 2016 - por. tab. 1, kolumna H; ryc. 1) należy stwierdzić, że SIDS są zróżnicowane wewnętrznie pod względem poziomu rozwoju społecznego. Żadne z państw nie uzyskało bardzo wysokiego HDI (powyżej 0,800). W 17 krajach poziom rozwoju społecznego był wysoki (przyjmując za graniczną wartość średnią arytmetyczną HDI dla 188 państw w 2015 roku w wysokości 0,699 - zob. ryc. 1). W tej grupie wyraźne jest rozwarstwienie na dwie podgrupy. Państwa o najwyższym poziomie rozwoju to: Barbados, Bahamy, Palau, Antigua i Barbuda, Seszele, Mauritius, Trynidad i Tobago, St. Kitts i Nevis oraz Grenada (wskaźnik w przedziale 0,795-0,750), a o niższym HDI: Fidżi, St. Lucia, Jamajka, Dominika, St. Vincent i Grenadyny, Wyspy Tonga, Samoa oraz Malediwy (wskaźnik od 0,736 do 0,700). W pozostałych dziewięciu państwach (o niższym od średniej światowej HDI) również wyraźne jest rozwarstwienie na dwie podgrupy. Państwa o wskaźniku powyżej 0,550 to: Republika Zielonego Przylądka, Federacyjne Stany Mikronezji, Timor Wschodni, Vanuatu, Kiribati, Wyspy Świętego Tomasza

3 Za wyznacznik małego państwa przyjąć można, oprócz niewielkiej gospodarki (mierzonej PKB czy PNB), niewielką liczbę ludności (np. mniej niż 1 mln mieszkańców) oraz niewielką powierzchnię terytorium (np. 20 tys. $\mathrm{km}^{2}$ ) (por. Briguglio, 2011: 251). L. Briguglio (uznany na świecie maltański specjalista z zakresu subdyscypliny ekonomii określonej jako Island economics) przyjmuje np. tylko wielkość populacji za wyznacznik małego państwa. Zgodnie z tym punktem widzenia „małe” państwo ma populację do 3 mln obywateli, powyżej tej liczby państwo jest już „duże”. Spojrzenie to wydaje się być mocno kontrowersyjne. 
i Książęca oraz SIDS o najniższym poziomie rozwoju społecznego (HDI poniżej 0,550) Papua Nowa Gwinea, Wyspy Salomona i Związek Komorów.

Przyjmując koncepcję wskaźnika HDI jako syntetycznej miary rozwoju społecznego, należy wyraźnie zaznaczyć, że występuje dodatnia zależność pomiędzy stopniem rozwoju a zamożnością. Wynika to m.in. z konstrukcji HDI, w przypadku którego jednym ze wskaźników cząstkowych jest poziom produktu na osobę, a poziomy pozostałych dwóch wskaźników cząstkowych zależą od zamożności społeczeństwa (Bartkowiak, 2013; Human Development Report, 2016).

Analiza wskaźnika dochodu per capita (w PPP) wskazuje na znaczne dysproporcje pomiędzy dochodem na osobę $\mathrm{w}$ poszczególnych małych państwach wyspiarskich. Wśród sześciu najzamożniejszych (granicę stanowi średnia arytmetyczna dla 193 państw wynosząca w 2015 roku 17,240 tys. dol. - zob. tab. 1, komuna I; ryc. 1) dominuje Trynidad i Tobago, w przypadku którego wskaźnik jako jedyny przekroczył 25 tys. dol. per capita. Następnie w przedziale pomiędzy 25 tys. a 20 tys. dol. znajdują się cztery państwa (Seszele, Saint Kitts i Nevis, Bahamy oraz Antigua i Barbuda), zaś w przedziale poniżej 20 tys. dol. - Mauritius.

W grupie o niższym od (światowego) przeciętnego dochodu na osobę (poniżej 17,240 tys. dol.) w przedziale od 15 do 10 tys. dol. zaklasyfikowano siedem SIDS Barbados, Palau, Nauru, Grenadę, Malediwy, St. Vincent i Grenadyny oraz Dominikę. W przedziale od 10 tys. do 5 tys. dol. znalazło się osiem małych państw wyspiarskich St. Lucia, Jamajka, Fidżi, Republika Zielonego Przylądka, Tuvalu, Samoa, Timor Wschodni oraz Wyspy Tonga. Do państw najbiedniejszych - poniżej 5 tys. dol. na osobę - należą Wyspy Marshalla, Federacyjne Stany Mikronezji, Wyspy Świętego Tomasza i Książęca, Vanuatu, Papua Nowa Gwinea, Kiribati, Wyspy Salomona oraz Związek Komorów.

\section{TURYSTYCZNA STRATEGIA ROZWOJU A OBECNY JEGO POZIOM W SIDS}

Wewnętrzne zróżnicowanie poziomu rozwoju społeczno-gospodarczego $\mathrm{w}$ analizowanych SIDS jest efektem nie tylko odmiennych uwarunkowań (przyrodniczych, historycznych czy społecznych), ale również nierównomiernego tempa włączania się w światową gospodarkę (Jędrusik, 2005). Analiza zachowań gospodarczych po rozpadzie systemu kolonialnego wskazuje, że istotne w procesie rozwoju, decydujące o jego obecnym poziomie, było dynamiczne włączenie się w światową gospodarkę poprzez eksport produktu turystycznego. W początkowej fazie na wyspach karaibskich (w latach pięćdziesiątych, sześćdziesiątych i siedemdziesiątych XX wieku) wraz z intensyfikacją specjalizacji turystycznej doszło do wypierania (zgodnie z twierdzeniem Rybczyńskiego - zob. Budnikowski, 2017) tradycyjnych form gospodarowania (monokultura cukrowa), w konsekwencji do skrajnej turystycznej choroby holenderskiej czy ujmując z perspektywy naszych rozważań - monokultury turystycznej (Jasiński, 2006; 2010; 2017b).

Rozwój infrastruktury turystycznej połączony z rozwojem infrastruktury transportowej (jak i rozwojem społeczno-gospodarczym) w znacznej części wysp karaibskich umożliwił rozszerzenie działalności o usługi finansowe (oazy podatkowe). W tej fazie (w latach osiemdziesiątych XX wieku) czynniki te były niezbędne. Oazy musiały dysponować dobrze rozwiniętą infrastrukturą komunikacyjną oraz (wysoce) wykwalifikowaną (posługującą się wieloma językami) kadrą (doradców biznesowych, księgowych, adwokatów, notariuszy itd.). Współcześnie cechy te są pożądane w mniejszym 
stopniu, co wynika z możliwości wirtualnych operacji finansowych. Niezbędną cechą pozostaje jednak posiadanie (względnie) liberalnego systemu prawnego i stabilnej sytuacji ekonomiczno-politycznej (Grzywacz, 2010). Spośród 29 badanych SIDS jako pierwsze przyjęły strategię turystyczną (karaibskie) Antigua i Barbuda, Bahamy i Barbados, stając się wzorem dla pozostałych małych państw wyspiarskich (Jasiński, 2010; 2017b). Obecnie są one państwami o najwyższym poziomie rozwoju społecznego (por. tab. 1, ryc. 1).

Wyspy, które nie włączyły się w szerszym zakresie w początkowej fazie postkolonialnej w światową gospodarkę turystyczną (głównie pacyficzne, Oceanu Indyjskiego i Atlantyku Wschodniego), pozostały w fazie gospodarki tradycyjnej (rolnictwo, rybołówstwo, rzemieślnictwo). Wraz z rozrostem światowego systemu pomocy rozwojowej w większości przypadków zostały zamknięte (zakleszczone) w monokulturze pomocowej (Jasiński, 2010; 2017a). W państwach tych pomoc rozwojowa dostarczana w długim okresie i w znacznych wielkościach paradoksalnie spowodowała wolniejszy rozwój (Bertram, 2013; Jasiński, 2017a; 2017b). Współcześnie małe gospodarki wyspiarskie, opierające swoją egzystencję $\mathrm{w}$ dominującym stopniu na pomocy rozwojowej (m.in. Federacyjne Stany Mikronezji, Kiribati, Nauru, Republika Zielonego Przylądka, Timor Wschodni, Tuvalu, Vanuatu, Wyspy Marshalla, Wyspy Salomona, Wyspy Świętego Tomasza i Książęca, Związek Komorów), są najbiedniejszymi i najsłabiej rozwiniętymi spośród badanych SIDS (por. tab. 1, kolumna H i I; ryc. 1).

Na tych dwóch skrajnych biegunach rozwoju należy umiejscowić państwa, które w późniejszych okresach fazy postkolonialnej włączały się w nurty światowej gospodarki turystycznej. W dużym uproszczeniu, przy analizie wpływu gospodarki turystycznej na proces rozwoju społeczno-ekonomicznego danego SIDS istotne wydaje się uwzględnienie trzech kwestii: (1) czasu (okresu), w którym zaczęto zmieniać orientację gospodarczą na turystyczną (kiedy nastąpił, zgodnie z koncepcją zależności od ścieżki, tzw. punkt zwrotny - por. Jasiński, 2010), jaki okres (jak długo) funkcjonuje gospodarka turystyczna; (2) z jaką intensywnością gospodarka turystyczna (zgodnie z twierdzeniem Rybczyńskiego) wyparła inne formy gospodarowania, tzn. jak duży jest sektor turystyczny względem całej gospodarki (jak silnie nasycona jest gospodarka turystyką) oraz (3) sposób zarządzania (całą) gospodarką (kontrola nad nią, w tym szczególnie umiejętne wkomponowanie gospodarki turystycznej w całość procesów gospodarczych).

Zgodnie z wcześniejszymi uwagami - im wcześniej nastąpiła faza intensywnego włączenia w światową gospodarkę turystyczną, tym wyższy jest poziom rozwoju i trwalsze są efekty społeczno-ekonomiczne. W przypadku części SIDS widoczna jest również zasada, zgodnie z którą państwa doganiające rozwijają się dynamiczniej niż prekursorzy.

Bardzo dobrym przykładem takiego państwa jest Palau. Pomimo pozostawania przez dziesięciolecia po II wojnie światowej w izolacji od światowej gospodarki (podobnie jak inne wyspy pacyficzne), wraz z uzyskaniem niepodległości (spod protektoratu Stanów Zjednoczonych Ameryki w 1994 roku) intensywnie włączyło się w światową gospodarkę turystyczną (Jasiński, 2017b). Obecnie duże znaczenie tego sektora w rozwoju potwierdzają (przytoczone) dane statystyczne (zob. tab. 1, kolumna I; tab. 2, EPT per capita).

Wpływy na jednego mieszkańca z tytułu eksportu produktu turystycznego w 2015 roku wynosiły 7,429 tys. dol. i były największe spośród badanych SIDS. Dodatkowo 
zestawienie ich z dochodem per capita $(13,771$ tys. dol.) wskazuje na duże znaczenie turystyki względem całej gospodarki (blisko 54\%), potwierdzając tym samym, że gospodarka Palau jest zaawansowaną monokulturą turystyczną. Analiza wskaźnika TPI (i jego składników cząstkowych) sygnalizuje, że państwo to jest blisko granicy nasycenia gospodarki turystyką - szczególnie jeżeli weźmiemy pod uwagę wskaźnik SU (najwyższy spośród SIDS). Wskazuje to na potrzebę ewentualnych korekt w prowadzeniu polityki turystycznej. Duże przeciążenie przestrzeni wskazuje, że dalsza perspektywa rozwoju gospodarki turystycznej musi uwzględniać niski próg nasycenia turystyką w tym (niewielkim powierzchniowo) państwie. Intensywne włączenie się w latach dziewięćdziesiątych XX wieku w światową gospodarkę turystyczną przyczyniło się na Palau do przyspieszenia procesów rozwojowych (obecnie najwyższego poziomu spośród pacyficznych SIDS) i dołączenia do najwyżej rozwiniętych małych państw wyspiarskich na świecie (por. ryc. 1).

Specyficzne przyspieszenie wzrostu gospodarczego (zapoczątkowane przez turystykę na początku lat siedemdziesiątych XX wieku) nastąpiło na Malediwach. Państwo to zostało jednak zamknięte w silnej monokulturze turystycznej (wpływy z turystyki stanowiły w 2015 roku ponad 70\% łącznego dochodu państwa - por. tab. 1, kolumna I i tab. 2, EPT per capita) i poza rybołówstwem właściwie nie rozwija innej (pozaturystycznej) działalności gospodarczej. Ponadto sama forma prowadzonej polityki turystycznej w tym kraju jest silnie krytykowana.

Rozwój gospodarki turystycznej przebiega na Malediwach według specyficznego modelu izolacji (Jędrusik, 2003). Charakteryzuje się on m.in. brakiem udziału w zyskach z tytułu turystyki przyjazdowej przez ludność lokalną. Odzwierciedleniem takiej polityki turystycznej jest znaczna dysproporcja pomiędzy zamożnością a rozwojem społecznym (por. ryc. 1). Tempo wzrostu gospodarczego nie przekłada się na „poprawę standardów cywilizacyjnych i polepszenie bytu ludności" (Piasecki, 2003: 16), co powinno stanowić kwintesencję rozwoju w przypadku państw rozwijających się. W wyniku tego np. UNCTAD (2010) klasyfikuje Malediwy do grupy państw najbiedniejszych wraz z takimi SIDS, jak: Kiribati, Samoa, Timor Wschodni, Tuvalu, Vanuatu, Wyspy Salomona, Wyspy Świętego Tomasza i Książęca oraz Związek Komorów. W wyniku silnej monokultury turystycznej, podobnie jak Palau, Malediwy również przy zastosowaniu wskaźnika TPI wykazują zbliżanie się do nasycenia gospodarki turystyką (najwyższy wskaźnik TPI - zob. tab. 2).

Odmienny sposób zarządzania gospodarką turystyczną zaobserwować można na Seszelach i na Mauritiusie, w których początki rozwoju tego sektora sięgają również, jak w przypadku Malediwów, pierwszej połowy lat siedemdziesiątych XX wieku. W obu SIDS gospodarka turystyczna rozwijana jest jednak w specyficznej równowadze. Nie jest nakierunkowana na dynamiczny, ilościowy wzrost przyjazdowego ruchu turystycznego. Turystyka jest (w miarę uwarunkowań) wkomponowana w całą gospodarkę. Towarzyszą jej inne sektory (gałęzie), m.in. rolnictwo, przemysł przetwórczy i sektor usług finansowych. W przypadku Mauritiusa, charakteryzującego się średnim nasyceniem gospodarki turystyką, „obowiązuje filozofia stania na wielu nogach” (Garbicz, 2012: 69) - dywersyfikacja. Rozwijane są pozostałe dziedziny gospodarki, co wydaje się być podstawą sukcesu społeczno-ekonomicznego tego małego, wyspiarskiego, afrykańskiego państwa (Jasiński, Masłoń-Oracz, 2017).

Analogiczne spostrzeżenia można mieć w stosunku do Barbadosu, który pomimo wysokiego wskaźnika nasycenia gospodarki turystyką jest państwem o (względnie) 
zdywersyfikowanej, rozwiniętej gospodarce. Pomimo zbliżania się do zjawiska monokultury turystycznej (wpływy z turystyki stanowiły w 2015 roku ponad 23\% łącznego dochodu państwa - por. tab. 1, kolumna I i tab. 2, EPT per capita), należy mieć na względzie jego najwyższy poziom rozwoju społecznego spośród analizowanych SIDS oraz fakt posiadania bardzo niskiego progu nasycenia gospodarki turystyką, wynikającego $\mathrm{z}$ bardzo małego terytorium $\left(430 \mathrm{~km}^{2}\right)$.

Na marginesie tych rozważań trzeba wskazać również na dwa państwa: Trynidad i Tobago oraz Papuę Nową Gwineę. SIDS, które są najbardziej dyskusyjne, jeżeli chodzi o zaklasyfikowanie ich do grupy małych państw wyspiarskich (por. przypisy 1 i 3 ). Pierwsze z nich, pomimo niewielkiego znaczenia gospodarczego turystyki (niski stopień nasycenia gospodarki turystyką), znajduje się wśród państw najwyżej rozwiniętych. W przypadku Trynidadu i Tobago wynika to $\mathrm{z}$ wysoko rozwiniętego sektora wydobycia i przetwórstwa ropy (eksport towarowy). Turystyczna specjalizacja nie jest jedyną możliwością tego państwa. Papua Nowa Gwinea zaś (podobnie jak Trynidad i Tobago jest w niskim stopniu nasycona turystyką) charakteryzuje się bardzo niskim poziomem rozwoju społeczno-gospodarczego, co przemawia za słusznością (koniecznością) podążania ścieżką turystyczną w procesie rozwoju społeczno-gospodarczego tego państwa.

\section{PODSUMOWANIE}

Na podstawie analizy wskaźnika TPI w 29 małych rozwijających się państwach na świecie stwierdzono, że stopień nasycenia gospodarki turystyką był w: ośmiu przypadkach - wysoki, w 10 - średni, w siedmiu - niski. W pozostałych czterech przypadkach, pomimo braku pełnych danych, przyjęto niski poziom nasycenia gospodarki turystyką.

Następnie, przy zastosowaniu wskaźnika HDI oraz wskaźnika cząstkowego dochodu na osobę (w PPP, w dol.), dokonano klasyfikacji analizowanych SIDS. Badanie wykazało, że w sześciu państwach wskaźnik rozwoju społecznego i dochód per capita był wysoki (powyżej średniej światowej), w 17 zaś rozwój społeczny był wysoki, przy niższych od przeciętnych (światowych) dochodów na osobę. W dziewięciu przypadkach poziom rozwoju społecznego i zamożności był niski, z czego w trzech przypadkach skrajnie niski. W pozostałych trzech przypadkach nie można było dokonać klasyfikacji z powodu braku pełnych danych. W jednym stwierdzono niski poziom zamożności (niższy od przeciętnego na świecie).

Niniejsze badania umożliwiły potwierdzenie postawionej tezy, która zakładała, że stopień nasycenia gospodarki przez turystykę determinuje poziom rozwoju społeczno-ekonomicznego SIDS. W przypadkach, gdy stopień ten był wysoki i średni, rozwój był wyższy. W przypadkach niskiego stopnia nasycenia gospodarki turystyką poziom rozwoju był w przeważającej liczbie niski bądź bardzo niski.

Dalsza analiza umożliwiła także wykazanie, że w dwóch przypadkach (Palau, Malediwy) intensywny rozwój gospodarki turystycznej, doprowadzający do bardzo silnego nasycenia gospodarki turystyką (skrajna monokultura turystyczna) przyczynił się do dynamicznego doganiania w ostatnich dziesięcioleciach najwyżej rozwiniętych gospodarek SIDS. Proces ten nie przebiega jednak bez konsekwencji. W szerszym kontekście należy uznać monokulturę turystyczną za specyficzną (niezbędną) fazę, przez którą muszą przejść SIDS w procesie rozwoju społeczno-gospodarczego. Jest to „choroba wieku dziecięcego" dla tych młodych, rozwijających się gospodarek. 


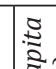

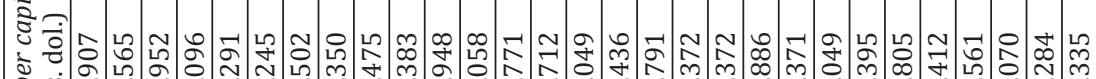

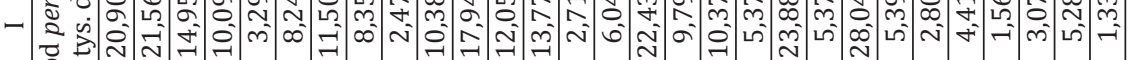

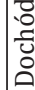

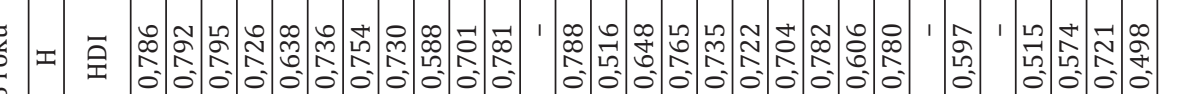

3

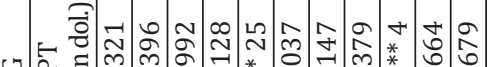

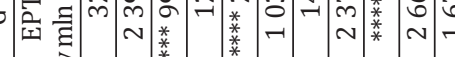

吕 m

흄

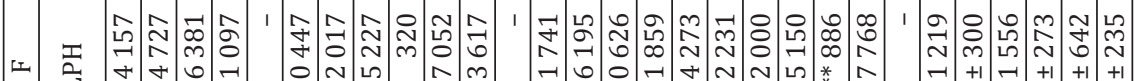

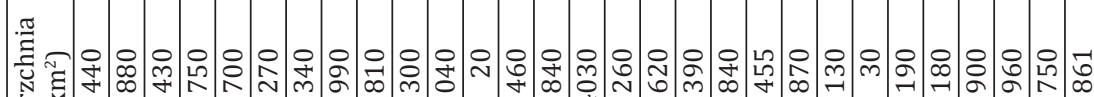

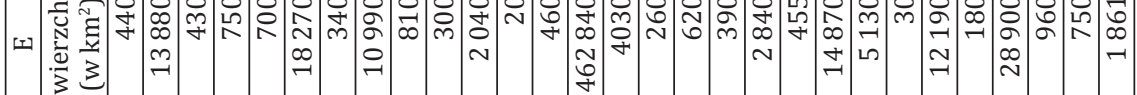
3.

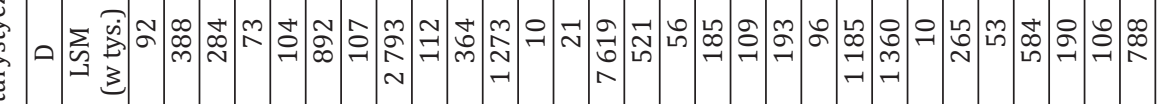

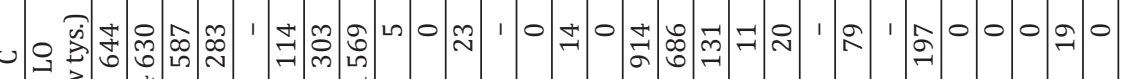

కై

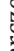

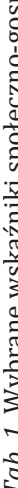

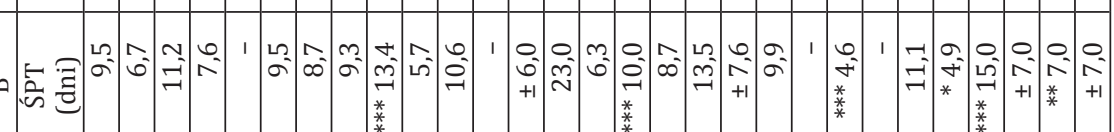

잉

क

気

(3)

:=

$\sim-1$ 


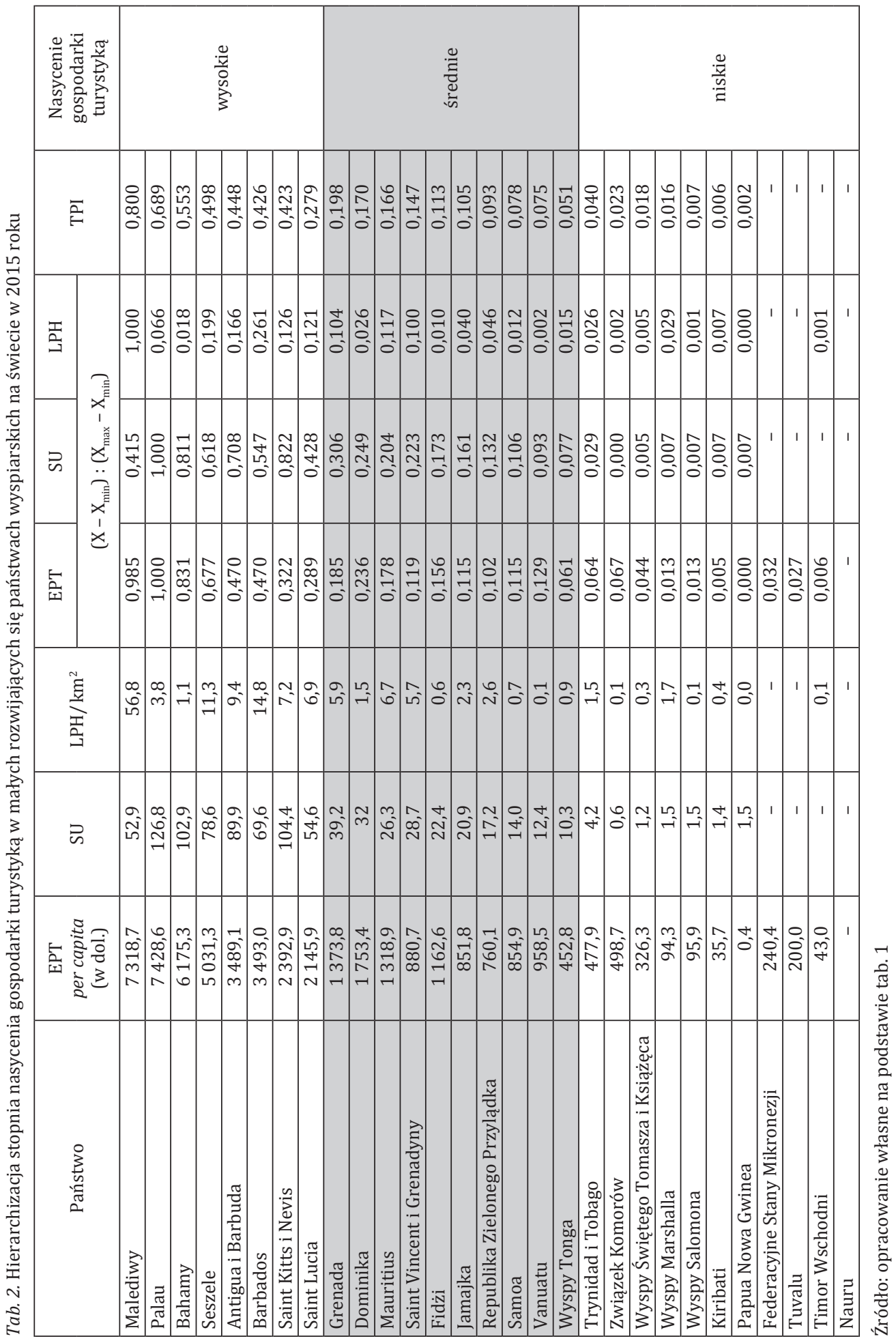




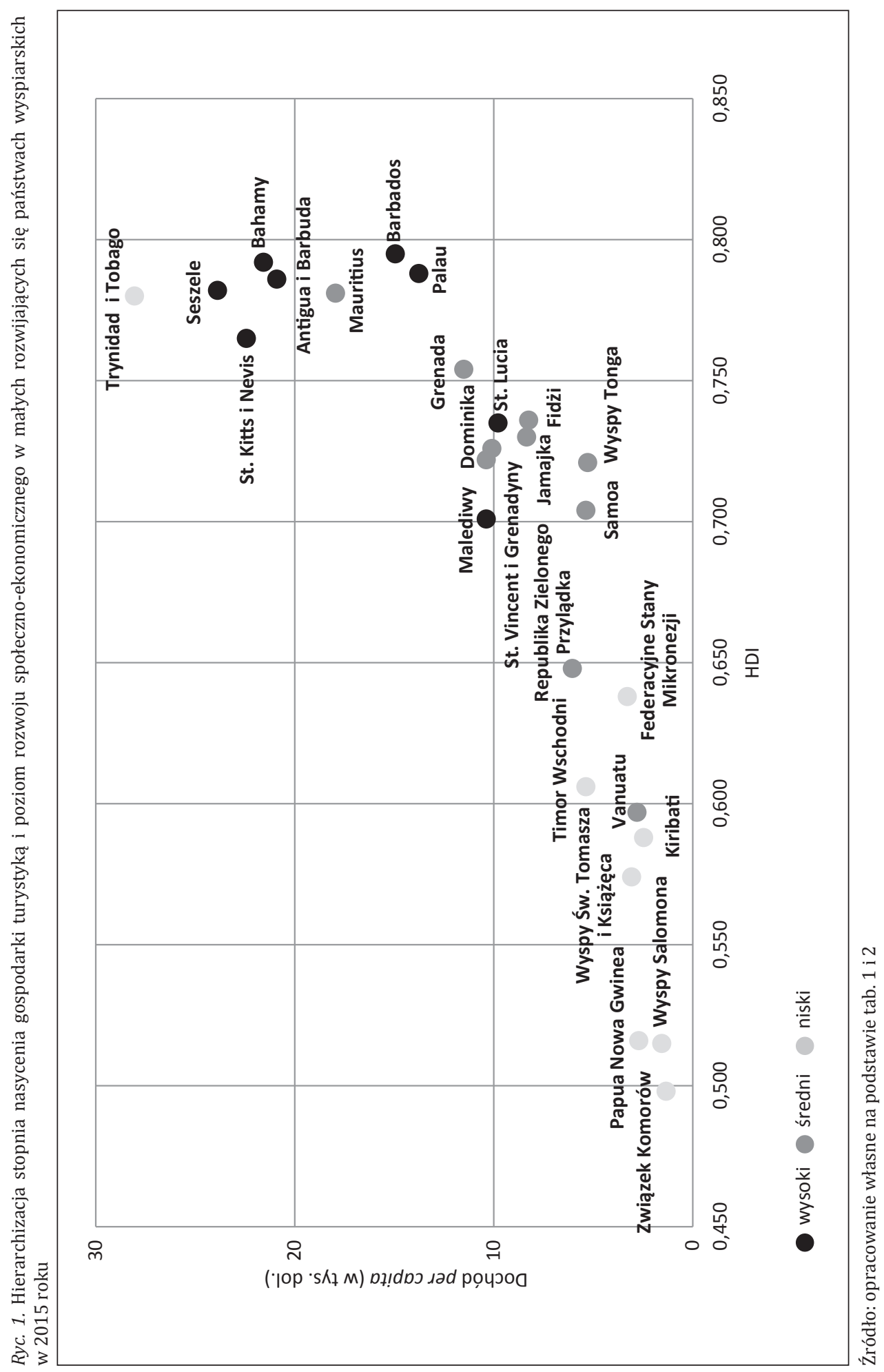




\section{Literatura \\ References}

Bank Światowy (2017). Pozyskano z https://data.worldbank.org/

Bartkowiak, R. (2013). Ekonomia rozwoju. Warszawa: Polskie Wydawnictwo Ekonomiczne.

Bertram, G. (2013). Pacific Island Economies. W: M. Rapaport (red.). The Pacific Islands: Environment and Society. Hawai'i University Press.

Briguglio, L. (2011). Macroeconomics and the Maltese Economy. Malta: BDL Publishing.

Budnikowski, A. (2017). Ekonomia międzynarodowa. Warszawa: Polskie Wydawnictwo Ekonomiczne.

Encontre, P. (2004). SIDS as a category: adopting criteria would enhance credibility. W: Is a special treatment of small island developing States possible? UNCTAD.

Garbicz, M. (2012). Problemy rozwoju i zacofania ekonomicznego. Dlaczego jedne kraje sq biedne, podczas gdy inne sa bogate? Warszawa: Wolters Kluwer.

Giezgała, J. (1969, 1977). Turystyka w gospodarce narodowej. Warszawa: Polskie Wydawnictwo Ekonomiczne.

Grzywacz, J. (2010). Pranie pieniędzy. Metody. Raje podatkowe. Zwalczanie. Warszawa: Oficyna Wydawnicza Szkoły Głównej Handlowej w Warszawie.

Hein, P. (2004). Small island developing States: origin of the category and definition issues. W: Is a special treatment of small island developing States possible? UNCTAD.

Human Development Report (2016). New York: United Nations Development Program.

Jasiński, M. (2006). Aspekty monokulturowe gospodarki turystycznej. Zeszyty Naukowe Kolegium Gospodarki Światowej Szkoły Głównej Handlowej w Warszawie, 20, 92-102.

Jasiński, M. (2008a). Turystyka a małe gospodarki wyspiarskie. Zeszyty Naukowe Kolegium Gospodarki Światowej Szkoły Głównej Handlowej w Warszawie, 23, 195-218.

Jasiński, M. (2008b). Zrównoważony rozwój w monokulturowych gospodarkach turystycznych. W: S. Wodejko (red.). Zrównoważony rozwój turystyki. Warszawa: Oficyna Wydawnicza Szkoły Głównej Handlowej.

Jasiński, M. (2010). Teoria zależności od ścieżki a małe gospodarki wyspiarskie. Zeszyty Naukowe Kolegium Gospodarki Światowej Szkoły Głównej Handlowej w Warszawie, 28, 52-72.

Jasiński, M. (2013). Kolonizacja turystyczna jako element rozwoju gospodarek wyspiarskich. Warszawa: Szkoła Główna Handlowa (rozprawa doktorska).

Jasiński, M. (2017a). Aspekty monokulturowe pomocowej choroby holenderskiej. Kwartalnik Kolegium Ekonomiczno-Społecznego Szkoły Głównej Handlowej w Warszawie. Studia i Prace, 3(31), 151-167.

Jasiński, M. (2017b). Modele rozwoju gospodarczego a poziom rozwoju społecznego i zamożności w małych państwach wyspiarskich na świecie. Studia i Prace. Wydział Nauk Ekonomicznych i Zarzq̨dzania Uniwersytetu Szczecińskiego, 49(2), 317-333.

Jasiński, M., Masłoń-Oracz, A. (2017). Rolnictwo i turystyka w rozwoju społeczno-ekonomicznym Mauritiusa. Zeszyty Naukowe Szkoły Głównej Gospodarstwa Wiejskiego w Warszawie. Problemy Rolnictwa Światowego, 17(3), 145-153.

Jędrusik, M. (2003). Trzy modele kolonizacji turystycznej na przykładzie archipelagów mórz ciepłych. Przegląd Geograficzny, 1(75), 81-100.

Jędrusik, M. (2005). Wyspy tropikalne. W poszukiwaniu dobrobytu. Warszawa: Wydawnictwo Uniwersytetu Warszawskiego.

Kachniewska, M., Niezgoda, A., Pawlicz, A. (2012). Globalizacja i internacjonalizacja działalności turystycznej. W: M. Kachniewska, E. Nawrocka, A. Niezgoda, A. Pawlicz (red.). Rynek turystyczny. Ekonomiczne zagadnienia turystyki. Warszawa: Wolters Kluwer.

Kowalczyk-Anioł, J. (2017). Społeczno-ekonomiczne dysfunkcje rozwoju monokultury turystycznej na wschodnim wybrzeżu meksykańskiego Jukatanu. Ekonomiczne Problemy Turystyki, 1(37), 209-222.

McElroy, J.L. (2003). Tourism Development in Small Islands across the World. Geografiska Annaler, 85(B)/4, 231-242.

McElroy, J.L. (2004). Global perspectives of Caribbean tourism. W: D.T. Duval (red.). Tourism in the Caribbean: Trends, Development, Prospects. London \& New York: Routledge, 39-56. 
McElroy, J.L. (2006). Small island tourist economies across the life cycle. Asia Pacific Viewpoint, 47(1), 61-77.

McElroy, J.L., de Albuquerque, K. (1998). Tourism penetration index in small Caribbean islands. Annals of Tourism Research, 25(1), 145-168.

Meyer, B. (2008). Kształtowanie układów przestrzenno-funkcjonalnych przez turystykę. Szczecin: Wydawnictwo Naukowe Uniwersytetu Szczecińskiego.

Mirkowska-Ostatek, M. (2013). Oficjalna pomoc rozwojowa jako czynnik eliminujący skalę ubóstwa w państwach Trzeciego Świata. W: E. Latoszek, M. Proczek (red.). Polityka rozwojowa. Rola organizacji międzynarodowych $w$ zwalczaniu ubóstwa na świecie. Warszawa: Oficyna Wydawnicza Szkoły Głównej Handlowej.

Padilla, A., McElroy, J.L. (2005). Tourism Penetration Index in Large Islands: The Case of the Dominican Republic. Journal of Sustainable Tourism, 13(4), 353-372.

Piasecki, R. (2003). Rozwój gospodarczy a globalizacja. Warszawa: Polskie Wydawnictwo Ekonomiczne.

Samoa Tourism Sector Plan (2013). Samoa Tourism Sector Plan 2014-2019. Samoa Tourism Authority.

Sen, A. (2002). Rozwój i wolność. Poznań: Zysk i S-ka.

UNCTAD (2010). In-depth evaluation of UNCTAD's technical cooperation activities dedicated to least developed countries, landlocked developing countries, small island developing states and other structurally weak, vulnerable and small economies.

UNWTO (2017). Compendium of Tourism Statistics. Madrid: UNWTO.

Włodarczyk, B. (2009). Przestrzeń turystyczna. Istota, koncepcje, determinanty rozwoju. Łódź: Wydawnictwo Uniwersytetu Łódzkiego.

Wodejko, S. (1998). Ekonomiczne zagadnienia turystyki. Warszawa: Wyższa Szkoła Handlu i Prawa.

Michał Jasiński, dr nauk ekonomicznych, Szkoła Główna Handlowa w Warszawie, Kolegium Ekonomiczno-Społeczne, Katedra Unii Europejskiej im. J. Monneta. Jego zainteresowania naukowe obejmują turystykę międzynarodową, pomoc rozwojową i małe rozwijające się gospodarki wyspiarskie (SIDS).

Michał Jasiński, Ph.D. in Economics, Warsaw School of Economics, Collegium of Socio-Economics, Jean Monnet Chair of the European Union. His research includes International Tourism, Official Development Assistance (ODA) and Small Island Developing States (SIDS).

\section{Adres/address:}

Szkoła Główna Handlowa w Warszawie

Kolegium Ekonomiczno-Społeczne

Katedra Unii Europejskiej im. J. Monneta

al. Niepodległości 162, 02-554 Warszawa, Polska

e-mail: michal.jasinski@sgh.waw.pl 